\title{
Assessing the phytotoxicity of cetrimonium bromide in plants using eco-physiological parameters
}

\author{
Uhram Song $^{*}$ and Han Eol Kim
}

\begin{abstract}
Background: Although cetrimonium bromide is widely used for its bactericidal effects, the safety of cetrimonium bromide remains controversial. Therefore, the phytotoxicity of cetrimonium bromide was tested to evaluate its acute toxicity to plants and possible toxicity to other organisms and the ecosystem.

Results: The germination rates of two test species, Lactuca sativa and Brassica campestris, were significantly decreased after cetrimonium bromide treatment. Furthermore, cetrimonium bromide treatment at over $1 \mathrm{mg} / \mathrm{L}$ concentration significantly affected root elongation immediately after germination. In pot experiments with semimature plants, significantly decreased shoot elongation and chlorophyll content were detected in both species following cetrimonium bromide treatment. Cetrimonium bromide treatment also significantly increased the antioxidant enzyme activities of plants.

Conclusion: Our results show that cetrimonium bromide is phytotoxic, and since phytotoxicity testing can imply potential toxicity in the environment, further studies of the environmental toxicity of cetrimonium bromide should be performed.
\end{abstract}

Keywords: Cetrimonium bromide, Toxicity, Germination, Elongation, Chlorophyll, Antioxidant enzyme activity

\section{Background}

Cetrimonium bromide, $\left(\mathrm{C}_{16} \mathrm{H}_{33}\right) \mathrm{N}\left(\mathrm{CH}_{3}\right)_{3} \mathrm{Br}$ (CAS no. 5709-0), also known as hexadecyl-trimethyl-ammonium bromide (International Union of Pure and Applied Chemistry [IUPAC] name), is an amine-based cationic quaternary surfactant that is widely used in components of antiseptic materials (Andersen 1997). Cetrimonium bromide is used in hygienic goods and cleaning agents for bactericidal effects (Oh et al. 2014) and in many cosmetics. However, recently there has been much debate about the safety of cetrimonium bromide (Woo 2015). Since cetrimonium bromide, which was present in many cosmetic products, was believed to be associated with human disease, the safety of this chemical has been questioned (Kim 2014). Furthermore, cetrimonium bromide is used in baby wet tissue wipes, resulting in much debate on its safety (Woo 2015). However, despite these problems, there are a very limited number of studies on the toxicity of this chemical.

\footnotetext{
* Correspondence: uhrami@jejunu.ac.kr

Department of Biology, Jeju National University, Jeju 63243, South Korea
}

Among the few studies, one research group reported an increase in fetal deaths in mice treated with $35.0 \mathrm{mg} / \mathrm{kg}$ cetrimonium bromide, although other studies of cetrimonium bromide did not show any acute toxicity (Andersen 1997). However, as there are only a few reports, further studies are required to determine the acute toxicity of cetrimonium bromide. Moreover, although cetrimonium bromide is commonly believed to be dangerous for the environment, especially in aquatic ecosystems, the toxicity of cetrimonium bromide to aquatic organisms is not well documented (Tišler et al. 2004). Therefore, further research on the ecotoxicity of cetrimonium bromide is required.

Phytotoxicity testing is often used to estimate potential toxicity in the environment and for risk assessment of chemicals and formulations of human relevance (Kristen 1997). Phytotoxicity tests are relatively simple but precise toxicological assays with sensitive results (Kristen 1997). Since the toxicity of cetrimonium bromide is still undetermined and its ecotoxicity is almost unknown, testing the toxicity of cetrimonium bromide with plants would supply further information on the toxicity and ecotoxicity of 
cetrimonium bromide. Therefore, in this study, the phytotoxicity of cetrimonium bromide was tested by evaluating seed germination rates, root elongation, and the ecophysiological responses of mature vegetable crops.

\section{Methods}

Cetrimonium bromide was purchased from Daejung Chemicals and Materials (Daejung C\&M, Gyonggi Province, Korea). The purity was above $99 \%$, and loss on drying at $100{ }^{\circ} \mathrm{C}$ was less than $2 \%$. We used $0.01 \mathrm{mg} / \mathrm{L}, 0.1 \mathrm{mg} / \mathrm{L}$, $1 \mathrm{mg} / \mathrm{L}, 10 \mathrm{mg} / \mathrm{L}, 100 \mathrm{mg} / \mathrm{L}$, and $1000 \mathrm{mg} / \mathrm{L}$ cetrimonium bromide solutions for testing by adding measured weight of cetrimonium bromide to distilled water. Although cetrimonium bromide is used at up to $10 \%$ concentration in cosmetics (Andersen 1997), we tested up to $1000 \mathrm{mg} / \mathrm{L}$ because animal toxicity was observed at a $10 \mathrm{mg} / \mathrm{L}$ concentration (Andersen 1997), and concentrations of approximately $29 \mathrm{mg} / \mathrm{L}$ can be found in wet tissues (Oh et al. 2014). Therefore, $0.01 \mathrm{mg} / \mathrm{L}, 0.1 \mathrm{mg} / \mathrm{L}$, and $1 \mathrm{mg} / \mathrm{L}$ treatments were selected for testing of environmentally realistic concentrations, and $10 \mathrm{mg} / \mathrm{L}, 100 \mathrm{mg} / \mathrm{L}$, and $1000 \mathrm{mg} / \mathrm{L}$ treatments were selected to test acute toxicity.

Seeds of Brassica campestris ssp. napus var. nippo-oleifera Makina (oilseed rape) and Lactuca sativa L. (lettuce) were selected to test the toxicity of cetrimonium bromide. These species were selected because they are common, easy to obtain, and included among the species recommended for the testing of chemicals in the Organisation for Economic Co-operation and Development guidelines (OECD, 2003). Seeds were purchased from a local Syngenta agent (Syngenta AG, Switzerland). The seeds were vernalized for 2 weeks and sterilized for $10 \mathrm{~min}$ in 10\% sodium hypochlorite solution (USEPA, 1996) before application.

For germination rate tests, seeds were soaked in cetrimonium bromide solutions for $24 \mathrm{~h}$ (Zheng et al. 2005) in the dark at room temperature with gentle shaking on an orbital shaker at $60 \mathrm{rpm}$ to improve mixing. Subsequently, the seeds were washed with distilled water. Most seeds were transferred to $100-\mathrm{mm}$ Petri dishes containing a piece of filter paper $(90 \mathrm{~mm})$ and $6 \mathrm{~mL}$ of distilled water (Lin and Xing 2007). The seeds were tested for germination in a growth chamber under a range of conditions established by the OECD guidelines (OECD, 2003): temperature $25{ }^{\circ} \mathrm{C}$, humidity $70 \pm 25 \%$, photoperiod $18 \mathrm{~h}$ light, light intensity $300 \mu \mathrm{E} \cdot \mathrm{m}^{-2} \cdot \mathrm{s}^{-1}$ with protection from drying. Each Petri dish $(n=5)$ contained five seeds, and germination rates were investigated for 1 week.

For root elongation studies, seeds were germinated in Petri dishes. After 2 days, germinated seeds were moved to new Petri dishes. Each Petri dish contained five seedlings and $5 \mathrm{~mL}$ of the test medium $(n=3)$. The root lengths of the seedlings were measured every 3 days (six times altogether). Other conditions, including solution concentrations and chamber conditions, were the same as those of the germination study, described above.

For pot experiment, plants were germinated and grown in a 50-hole pot tray with each hole filled with $10 \mathrm{~g}$ of commercial growing soil (Pro-100, Chamgrow, Korea). After a 5 -week growing period from the seedling stage, $10 \mathrm{~mL}$ of cetrimonium bromide solution was added to each pot $(0.01 \mathrm{mg} / \mathrm{L}, 0.1 \mathrm{mg} / \mathrm{L}, 1 \mathrm{mg} / \mathrm{L}, 10 \mathrm{mg} / \mathrm{L}, 100 \mathrm{mg} / \mathrm{L}$, and $1000 \mathrm{mg} / \mathrm{L}$; seven replicates for each treatment). Solutions were administered several times with a $1-\mathrm{mL}$ pipette to avoid leaching. Therefore, the growing soil contained exactly $0.01 \mathrm{mg} / \mathrm{kg}, 0.1 \mathrm{mg} / \mathrm{kg}, 1 \mathrm{mg} / \mathrm{kg}, 10 \mathrm{mg} / \mathrm{kg}$, $100 \mathrm{mg} / \mathrm{kg}$, and $1000 \mathrm{mg} / \mathrm{kg}$ of cetrimonium bromide. The chlorophyll content of leaves was measured using a SPAD 502 system (Minolta Co., Japan), 1 week after treatment. The antioxidant enzyme activities (total antioxidant capacity [TAC] and superoxide dismutase [SOD] activity) of the plants were measured using the protocols of Song and Lee, 2010, 1 week after treatment (five replicates). The average height of the shoots of the plants was $6.4 \pm 0.5 \mathrm{~cm}$ for Lactuca sativa, and $6.7 \pm 0.3 \mathrm{~cm}$ for Brassica campestris (values represent mean \pm SE of 49 replicates). Plant growth after treatment was also measured for 1 week.

A one-way ANOVA was performed to identify significant differences between treatments. Upon detection of a significant difference, Tukey's studentized range (honest significant difference) test was applied post hoc and assessed using SAS 9.3 software (SAS Institute Inc., USA). Differences were considered significant when $p<0.05$.

\section{Results and discussion}

Table 1 shows that cetrimonium bromide treatment significantly decreased the germination rates of both species. Specially for Lactuca sativa, the germination rate was significantly affected by cetrimonium bromide, even at $0.1 \mathrm{mg} / \mathrm{L}$, and germination was totally inhibited at $1000 \mathrm{mg} / \mathrm{L}$. Total inhibition of germination has not previously been observed in the authors' prior germination tests

Table 1 Germination rates (\%) of plants after cetrimonium bromide treatment

\begin{tabular}{llllll}
\hline Species & \multicolumn{2}{l}{ Lactuca sativa } & & \multicolumn{2}{l}{ Brassica campestris } \\
\cline { 2 - 3 } Treatment/days & 3 days & 6 days & & 3 days & 6 days \\
\hline Control & $98.0 \pm 2.0^{\mathrm{a}}$ & $100.0 \pm 0.0^{\mathrm{a}}$ & & $96.0 \pm 2.4^{\mathrm{a}}$ & $98.0 \pm 2.0^{\mathrm{a}}$ \\
$0.01 \mathrm{mg} / \mathrm{L}$ & $96.0 \pm 2.4^{\mathrm{a}}$ & $100.0 \pm 0.0^{\mathrm{a}}$ & $86.0 \pm 2.4^{\mathrm{ab}}$ & $86.0 \pm 2.4^{\mathrm{ab}}$ \\
$0.1 \mathrm{mg} / \mathrm{L}$ & $88.0 \pm 5.8^{\mathrm{a}}$ & $92.0 \pm 4.9^{\mathrm{a}}$ & $74.0 \pm 5.1^{\mathrm{abc}}$ & $78.0 \pm 4.9^{\mathrm{ab}}$ \\
$1 \mathrm{mg} / \mathrm{L}$ & $86.0 \pm 2.4^{\mathrm{a}}$ & $92.0 \pm 3.7^{\mathrm{a}}$ & $74.0 \pm 6.0^{\mathrm{abc}}$ & $76.0 \pm 5.1^{\mathrm{ab}}$ \\
$10 \mathrm{mg} / \mathrm{L}$ & $86.0 \pm 5.1^{\mathrm{a}}$ & $92.0 \pm 3.7^{\mathrm{a}}$ & $72.0 \pm 5.8^{\mathrm{bc}}$ & $76.0 \pm 7.5^{\mathrm{ab}}$ \\
$100 \mathrm{mg} / \mathrm{L}$ & $46.0 \pm 6.8^{\mathrm{b}}$ & $54.0 \pm 6.8^{\mathrm{b}}$ & $72.0 \pm 4.9^{\mathrm{bc}}$ & $76.0 \pm 5.1^{\mathrm{ab}}$ \\
$1000 \mathrm{mg} / \mathrm{L}$ & $0.0 \pm 0.0^{\mathrm{c}}$ & $0.0 \pm 0.0^{\mathrm{c}}$ & $64.0 \pm 6.8^{\mathrm{c}}$ & $66.0 \pm 6.8^{\mathrm{b}}$ \\
\hline
\end{tabular}

Values represent the mean \pm SE of five replicates

Means in a column with the same letter are not significantly different $(p>0.05)$ 
of toxins (Song, Jun et al. 2013; Song, Shin et al. 2013; Song et al. 2014); thus, cetrimonium bromide is considerably toxic to plants, in a similar manner to herbicides (Zonno and Vurro 2002). Although cetrimonium bromide significantly decreased the germination of Brassica campestris, this species was less affected than Lactuca sativa (Table 1). As the seed coat of Brassica campestris is harder and thicker than that of Lactuca sativa, the short time of exposure would not have been enough to penetrate the seed coat. Nevertheless, Brassica campestris showed a significantly reduced germination rate even at the lowest treatment concentration $(0.01 \mathrm{mg} / \mathrm{L})$, indicating that cetrimonium bromide is phytotoxic. Therefore, even for environmentally realistic conditions, cetrimonium bromide would likely damage plants when released into the environment. Figure 1 shows that cetrimonium bromide treatment significantly affected root elongation. In both species, treatment at over $1 \mathrm{mg} / \mathrm{L}$ concentrations significantly decreased root elongation when compared with that of the control. At $10 \mathrm{mg} / \mathrm{L}$, both species showed definite growth for the first 3 days
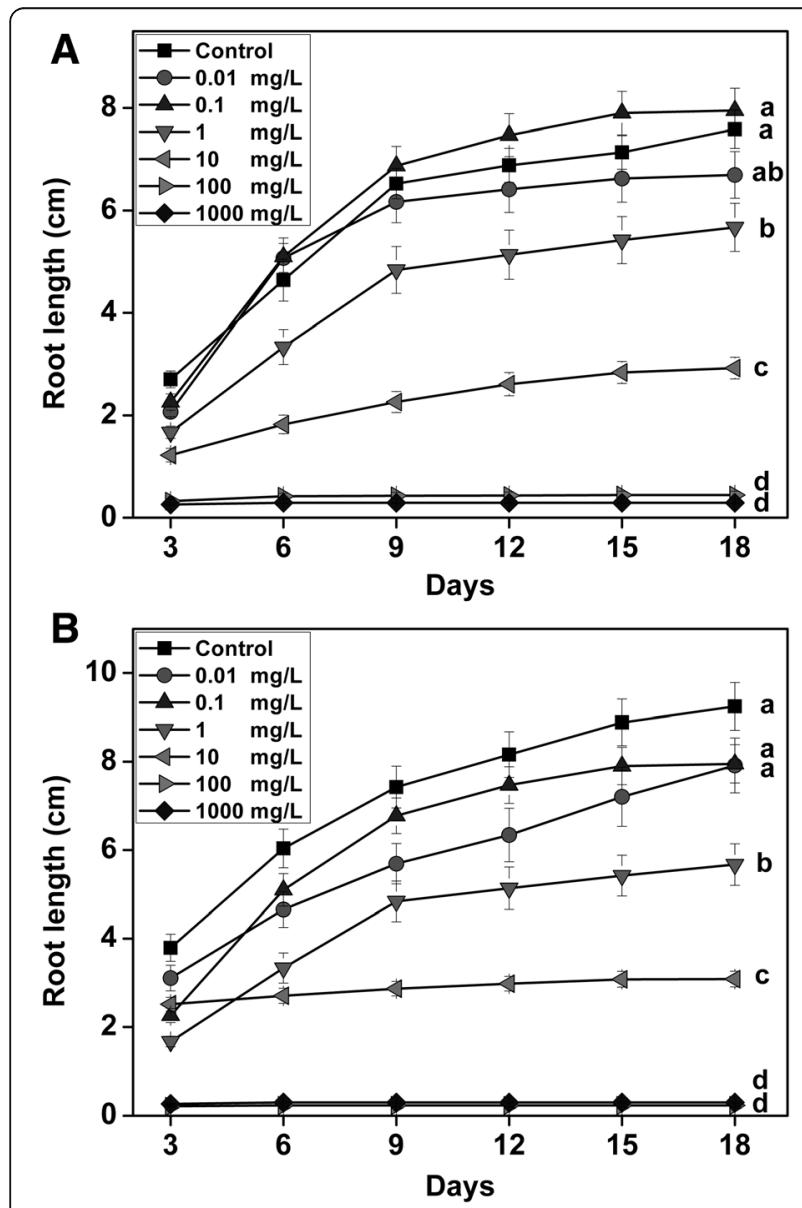

Fig. 1 Root elongation of a Lactuca sativa and $\mathbf{b}$ Brassica campestris after cetrimonium bromide treatment. Symbols and error bars represent the mean \pm SE of 20 replicates. Symbols with the same letters are not significantly different $(p>0.05)$ (especially for Brassica campestris, where there were no significant differences between the $10 \mathrm{mg} / \mathrm{L}$ treatment and control) but began to show significantly decreased root length over time, indicating that extended exposure to cetrimonium bromide was more toxic, probably because of accumulation. Furthermore, treatment at over $100 \mathrm{mg} / \mathrm{L}$ resulted in no root growth (Fig. 1), indicating that the seedlings were dead. These results show that cetrimonium bromide is phytotoxic at certain concentrations.

Cetrimonium bromide was also phytotoxic to plants beyond the seed and seedling stage. Table 2 shows that plants grown over 5 weeks showed a significant reduction in shoot elongation after cetrimonium bromide treatment. Lactuca sativa exhibited a significantly decreased shoot growth with treatments over $1 \mathrm{mg} / \mathrm{kg}$ in concentration, and Brassica campestris exhibited a significantly decreased shoot growth with treatments over $0.1 \mathrm{mg} / \mathrm{kg}$ in concentration. Moreover, the highest concentration treatment resulted in almost no growth for a week (Table 2). By contrast, $0.1 \mathrm{mg} / \mathrm{kg}$ treatment of Lactuca sativa and $0.01 \mathrm{mg} / \mathrm{kg}$ treatment of Brassica campestris resulted in approximately $10-20 \%$ greater growth than controls. This result is hard to explain because physiological parameters, such as chlorophyll content (Table 3) and antioxidant enzyme activity (Table 4), show that the plants were stressed even at these concentrations. One possible explanation is that since the plants were grown for 5 weeks, the soil became contaminated by microorganisms, which stressed the plants. At low concentrations, cetrimonium bromide would likely decrease the activity of these microorganisms and provide an advantage to the plants. However, this is only a hypothesis and the exact reason remains unknown. Overall, cetrimonium bromide significantly affected the growth of semi-mature plants.

Chlorophyll content was more sensitive to treatment, as both plant species showed significantly decreased chlorophyll content even at the lowest $(0.01 \mathrm{mg} / \mathrm{kg})$ concentration (Table 3). Especially with treatments over $100 \mathrm{mg} / \mathrm{kg}$ in concentration, both species lost chlorophyll and began to fade. As the environmentally realistic treatments all resulted

Table 2 Shoot elongation ( $\mathrm{mm}$ ) of plants 1 week after cetrimonium bromide treatment

\begin{tabular}{lcc}
\hline Treatment/species & Lactuca sativa & Brassica campestris \\
\hline Control & $3.4 \pm 0.6^{\mathrm{ab}}$ & $8.1 \pm 1.7^{\mathrm{ab}}$ \\
$0.01 \mathrm{mg} / \mathrm{kg}$ & $3.3 \pm 0.7^{\mathrm{abc}}$ & $10.1 \pm 1.7^{\mathrm{a}}$ \\
$0.1 \mathrm{mg} / \mathrm{kg}$ & $3.7 \pm 1.0^{\mathrm{a}}$ & $5.0 \pm 1.5^{\mathrm{ab}}$ \\
$1 \mathrm{mg} / \mathrm{kg}$ & $1.0 \pm 0.2^{\mathrm{bcd}}$ & $5.0 \pm 1.7^{\mathrm{ab}}$ \\
$10 \mathrm{mg} / \mathrm{kg}$ & $1.3 \pm 0.2^{\mathrm{abcd}}$ & $6.8 \pm 2.1^{\mathrm{ab}}$ \\
$100 \mathrm{mg} / \mathrm{kg}$ & $0.8 \pm 0.3^{\mathrm{cd}}$ & $1.8 \pm 0.8^{\mathrm{b}}$ \\
$1000 \mathrm{mg} / \mathrm{kg}$ & $0.0 \pm 0.0^{\mathrm{d}}$ & $0.2 \pm 0.1^{\mathrm{c}}$ \\
\hline
\end{tabular}

Values represent the mean \pm SE of seven replicates

Means in a column with the same letter are not significantly different $(p>0.05)$ 
Table 3 Chlorophyll content (SPAD-502 units) of plant leaves 1 week after cetrimonium bromide treatment

\begin{tabular}{lcc}
\hline Treatment/species & Lactuca sativa & Brassica campestris \\
\hline Control & $14.2 \pm 0.2^{\mathrm{a}}$ & $23.2 \pm 1.1^{\mathrm{a}}$ \\
$0.01 \mathrm{mg} / \mathrm{kg}$ & $11.2 \pm 0.3^{\mathrm{b}}$ & $21.5 \pm 0.3^{\mathrm{ab}}$ \\
$0.1 \mathrm{mg} / \mathrm{kg}$ & $10.2 \pm 0.3^{\mathrm{bc}}$ & $18.8 \pm 0.3^{\mathrm{bc}}$ \\
$1 \mathrm{mg} / \mathrm{kg}$ & $9.3 \pm 0.4^{\mathrm{c}}$ & $17.2 \pm 0.8^{\mathrm{c}}$ \\
$10 \mathrm{mg} / \mathrm{kg}$ & $9.4 \pm 0.2^{\mathrm{c}}$ & $16.7 \pm 0.6^{\mathrm{c}}$ \\
$100 \mathrm{mg} / \mathrm{kg}$ & $7.0 \pm 0.3^{\mathrm{d}}$ & $11.5 \pm 0.7^{\mathrm{d}}$ \\
$1000 \mathrm{mg} / \mathrm{kg}$ & $4.4 \pm 0.5^{\mathrm{e}}$ & $6.8 \pm 0.9^{\mathrm{e}}$
\end{tabular}

Values represent the mean \pm SE of seven replicates

Means in a column with the same letter are not significantly

different $(p>0.05)$

in significantly decreased chlorophyll content, cetrimonium bromide will likely affect plants in the field when it is released into the surrounding environment (ecosystem).

Notably, these results indicate that when the cetrimonium bromide used by humans enters aquatic ecosystems via sewage, the impact on aquatic plants could be considerable, and therefore the results should be monitored and investigated. The original experimental design intended to monitor plant growth and chlorophyll content for a few weeks, but since the plants treated at high concentrations began to fade and lose chlorophyll within 1 week (Table 3), we harvested the plants for antioxidant enzyme activity assays before the plants died. Table 4 shows the antioxidant enzyme activities of Lactuca sativa after cetrimonium bromide treatment. We intended to measure the antioxidant enzyme activities of both species; however, there was not enough Brassica campestris leaf biomass (over $1 \mathrm{~g}$ fresh weight) for protein extraction via a phosphate buffer and Bradford assay (Song and Lee 2010). The above ground biomass allocation of Brassica campestris was over $75 \%$ on stems, even in the control, and there was not enough leaf biomass. Cetrimonium bromide treatment significantly increased both the TAC and SOD values (Table 4), indicating that the plants were under stress (Song, Jun, et al. 2013). The TAC results

Table 4 Zinc accumulation in plants after exposure to zinc oxide nanoparticles for 5 weeks

\begin{tabular}{lcc}
\hline Zinc content $(\mathrm{mg} / \mathrm{kg})$ & Hydrilla verticillata & Phragmites australis \\
\hline Control & ND & $0.02 \pm 0.01^{\mathrm{c}}$ \\
0.01 & $0.08 \pm 0.01^{\mathrm{c}}$ & $0.22 \pm 0.01^{\mathrm{c}}$ \\
0.1 & $0.10 \pm 0.01^{\mathrm{c}}$ & $0.57 \pm 0.31^{\mathrm{bc}}$ \\
1 & $0.11 \pm 0.01^{\mathrm{c}}$ & $1.17 \pm 0.03^{\mathrm{ab}}$ \\
10 & $0.20 \pm 0.03^{\mathrm{b}}$ & $1.43 \pm 0.03^{\mathrm{a}}$ \\
100 & $0.35 \pm 0.01^{\mathrm{a}}$ & $1.47 \pm 0.03^{\mathrm{a}}$ \\
1000 & $0.34 \pm 0.01^{\mathrm{a}}$ & $1.67 \pm 0.22^{\mathrm{a}}$ \\
\hline
\end{tabular}

Values represent mean \pm SE of three replicates

Values with different letters are significantly different at the $p<0.05$ level, whereas those with the same letters are not in particular indicate that the plants were under overall stress, which may be reflected in the growth and chlorophyll content of the plants (Tables 2 and 3). SOD values are frequently used as an indicator of pollutant stress (Koricheva et al. 1997). Since plants treated at over $0.1 \mathrm{mg} /$ $\mathrm{kg}$ showed significantly increased SOD values, cetrimonium bromide should be treated as a potential pollutant. As bromine residues in the soil can cause phytotoxicity (Lear 1975), cetrimonium bromide clearly shows phytotoxicity. Overall, all of the above results, including the germination rate, root and shoot elongation, chlorophyll content, and antioxidant enzyme activity, consistently show that cetrimonium bromide is phytotoxic.

\section{Conclusion}

The germination rates of both Lactuca sativa and Brassica campestris species were significantly decreased after cetrimonium bromide treatment. Notably, both species showed total inhibition of germination with the $1000 \mathrm{mg} / \mathrm{L}$ treatment. Furthermore, cetrimonium bromide treatment significantly affected root elongation immediately after germination. In semi-mature plants, significant reductions in shoot elongation and chlorophyll content were detected in both species after cetrimonium bromide treatment. Antioxidant enzyme activities of the plants were also significantly increased by cetrimonium bromide. These results indicate that cetrimonium bromide is markedly phytotoxic. However, surprisingly there are no related articles that report the phytotoxicity of cetrimonium bromide. Since phytotoxicity testing can be used to estimate potential toxicity in the environment, our results show that cetrimonium bromide could also be toxic to other organisms and ecosystems when released into the surrounding environment. Also, as cetrimonium bromide is likely to be mostly released by hydrologic system as the chemical is mainly used for water and cosmetic treatment, the growth of vegetables also could be affected by irrigation. As only a few articles report the toxicity of cetrimonium bromide, and these are limited to human (Momblano et al. 1984) and mammal (Andersen 1997) toxicity, further studies to define the acute toxicity to other organisms and potential environmental toxicity should be performed. Furthermore, cetrimonium bromide should be carefully monitored for its effects after release into the surrounding environment and into edible crops. Therefore, further studies of the toxicity of cetrimonium bromide at both the species level and environmentecosystem level are required.

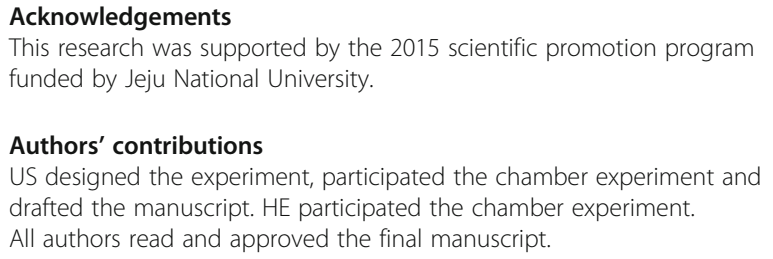




\section{Competing interests}

The authors declare that they have no competing interests.

Received: 11 May 2016 Accepted: 31 August 2016

Published online: 24 November 2016

\section{References}

Andersen, F. (1997). Final report on the safety assessment of cetrimonium chloride, cetrimonium bromide, and steartrimonium chloride. Int J Toxicol, 16, $195-220$.

Kim, SJ. (2014). Stricter safety standards on wet tissues, shampoo The Korea Times. https://www.koreatimes.co.kr/www/common/printpreview. asp? categoryCode $=116 \&$ newsld $x=169060$.

Koricheva, J, Roy, S, Vranjic, JA, Haukioja, E, Hughes, PR, \& Hänninen, O. (1997). Antioxidant responses to simulated acid rain and heavy metal deposition in birch seedlings. Environ Pollut, 95, 249-258.

Kristen, U (1997). Use of higher plants as screens for toxicity assessment. Toxicol in Vitro, 11, 181-191.

Lear, B (1975). Phytotoxicity associated with bromide uptake in plants grown in soil fumigated with brominated hydrocarbon. Nematologica, 5, 24.

Lin, D, \& Xing, B (2007). Phytotoxicity of nanoparticles: inhibition of seed germination and root growth. Environ Pollut, 150, 243-250.

Momblano, P, Pradere, B, Jarrige, N, Concina, D, Bloom, E (1984). Metabolic acidosis induced by cetrimonium bromide. Lancet, 324, 1045.

Oh, J, Kim, K, Pyo, H, Chung, BC, Lee, J (2014). External standard addition method development of benzalkonium chloride, cetrimonium bromide and cetylpyridinium chloride in wet-tissues by liquid chromatography-electrospray ionization/mass spectrometry (pp. 232-232). Proceedings of 53th symposium of the Korean society of analytical sciences.

Organization for Economic Cooperation and Development (OECD). (2003). OECD Guidelines for the testing of chemicals: Proposals for updating guideline 208 Terrestrial Plant Test: Seedling Emergence and Seedling Growth Test. http:// www.oecd.org/dataoecd/11/31/33653757.pdf

Song, U, Lee, E (2010). Ecophysiological responses of plants after sewage sludge compost applications. J Plant Biol, 53, 259-267.

Song, U, Jun, H, Waldman, B, Roh, J, Kim, Y, Yi, J, Lee, EJ. (2013). Functional analyses of nanoparticle toxicity: a comparative study of the effects of $\mathrm{TiO} 2$ and $\mathrm{Ag}$ on tomatoes (Lycopersicon esculentum). Ecotoxicol Environ Safety, 93, 60-67.

Song, U, Shin, M, Lee, G, Roh, J, Kim, Y, Lee, E (2013). Functional analysis of TiO2 nanoparticle toxicity in three plant species. Biol Trace Elem Res, 155, 93-103.

Song, U, Mun, S, Waldman, B, Lee, E (2014). Effects of three fire-suppressant foams on the germination and physiological responses of plants. Environ Manage, 54, 865-874.

Tišler, T, Zagorc-Končan, J, Cotman, M, Drolc, A (2004). Toxicity potential of disinfection agent in tannery wastewater. Water Res, 38, 3503-3510.

U.S. Environmental Protection Agency (USEPA). 1996. Ecological effects test guidelines (OPPTS 850.4200): Seed Germination/Root Elongation Toxicity Test. http://www.epa.gov/opptsfrs/publications/OPPTS_Harmonized/850_ Ecological_Effects_Test_Guidelines/Drafts/850-4200.pdf

Woo, HC (2015). Baby wipes raise health concerns The Korea Times. http://www. koreatimes.co.kr/www/news/biz/2014/09/123_164982.html. Accessed 21 Oct 2015.

Zheng, L, Hong, F, Lu, S, Liu, C (2005). Effect of nano-TiO(2) on strength of naturally aged seeds and growth of spinach. Biol Trace Elem Res, 104, 83-91.

Zonno, MC, Vurro, M (2002). Inhibition of germination of Orobanche ramosa seeds by Fusarium toxins. Phytoparasitica, 30, 519-524.

\section{Submit your next manuscript to BioMed Central and we will help you at every step:}

- We accept pre-submission inquiries

- Our selector tool helps you to find the most relevant journal

- We provide round the clock customer support

- Convenient online submission

- Thorough peer review

- Inclusion in PubMed and all major indexing services

- Maximum visibility for your research

Submit your manuscript at www.biomedcentral.com/submit
Biomed Central 